\title{
Evaluation of Banks' Commercial Credit Applications using the Analytic Hierarchy Process and Grey Relational analysis: A Comparison between Public ANd Private Banks
}

\author{
Zeliha Kaygısız Ertuğ and Nuray Girginer \\ Department of Business Administration, Eskişehir Osmangazi University
}

Accepted: February 2015

\begin{abstract}
The purpose of this study is to develop an evaluation model that considers the quantitative and qualitative criteria for the appropriate selection of firms demanding commercial credit for both public and private banks. In this paper, the authors propose an integrated model that combines the Analytic Hierarchy Process (AHP) and Grey Relational Analysis (GRA) into a single evaluation model. The model is illustrated with a case study on bank experts to demonstrate the effectiveness of this integrated method for four firms that applied for a commercial loan. In this study, AHP is applied to determine the weight of the criteria, and GRA is performed to determine the most appropriate firm. The results of this study indicate that, whereas firm morality and news criteria are the main criteria with the highest priority, sale and marketing constructions are the main criteria with the lowest priorities for both public and private banks. In addition, according to the results of GRA, the most appropriate firm for a public bank is Firm 1, and the most appropriate firm for a private bank is Firm 2.
\end{abstract}

Key words: decision analysis, commercial credit application, credit demand evaluation model, analytic hierarchy process, Grey relational analysis.

JEL: COO

\section{$1 \quad$ Introduction}

Although various functions and service areas differ on their founding objectives, banks, whose most essential function is to provide funds, are the financial institutions of fundamental importance that bring together those demanding and those supplying funds. Banks generally fulfill their function of providing funds with credit. Credit is the transaction of lending the obtained funds and equity capital of the banks to the natural and real entities within legal restrictions. This is done by considering the in-company statute of the bank itself on the condition that the loan will be reimbursed within a certain period of time according to the commitment to the debt. In developing countries in particular, the decisions made by the banking sector have a major impact on the country's economy, and the disruptions that may occur in the sector may even lead the country to the point of economic crisis. The decision to grant loans must therefore involve a decision-making process that is as efficient as possible. Inaccurate decisions made in granting loans result in credit risk, which may be expressed as the probability of non-payment of a loan. The bank encounters credit risk, which may be expressed as non-compliance with the requirements detailed in the credit contract, upon the failure of the debtor to partially or completely meet the obligation. There will more expectations that the bank loans will be reimbursed with efficient implementation and management of the crediting processes and in a way that will minimise the damages that occur on account of the credit risk.

According to today's changing conditions, the banks release various types of credit, addressing different customer needs as a consequence of the intense competition and rapid changes taking place. Ranging from commercial loans to consumer loans, housing loans and auto loans, the loans granted by the banks vary depending on the criteria, such as the maturity date, the purpose of use, the sector and area of use, as well as indemnification. Banks must offer credit in a way that enables the maximisation of the returns expected from commercial loans and the minimisation of the loss 
arising from credit risk. This requirement compels banks to face the issue of evaluating firms' credit demands.

The criteria that banks consider during the process of credit evaluation are important in reducing credit risk and the banks' being able to rely on accurate and efficient decision-making. The evaluation of firms' credit requires a complicated and multi-criteria decision. Several quantitative and qualitative criteria (financial structure, managerial structure, morality, intelligence, sectoral structure, sales and marketing structure, etc.) have to be addressed together. For this reason, the Analytic Hierarchy Process (AHP), which enables determination of the priorities that could affect the evaluation, is an appropriate technique for solving this problem. This is not to forget the assessment of all the criteria together, which reveals the degree of importance of each criterion. In other respects, Grey Relation Analysis (GRA) is another technique that may be used in the problem of evaluating the credit demands by firms. The technique ensures the selection of the best criteria according to the proximity of the best alternative.

Techniques such as multivariable statistical techniques, discriminant analysis, regression analysis, logistic regression analysis, and the probit model, as well as econometric analyses (Frame, Padhi \& Woosley, 2001; Lee, Pham \& Zhang, 1999; Bodur \& Teker, 2005; Abdou, Masry \& Pointon, 2007; Huang, Chen \& Wang, 2007) have been applied in the literature in relation to credit evaluation decisions, particularly in the measurement of credit risk. In addition to financial information, the existence of non-financial, i.e., quantitatively non-measurable factors, has led researchers to multi-criteria decision-making techniques like AHP, DEA (Data Envelopment Analysis) and PROMETHEE (Preference Ranking Organisation Method for Enrichment Evaluations) (Cheng, Chiang \& Tang, 2007; Babic \& Plazibat, 1998; Chen \& Chiou, 1999; Yurdakul, \& İç, 2004; Xu \& Zhang, 2009; Atan, Maden \& Akyıldız, 2004; Sekreter, Akyuz \& Çetin, 2004; Albayrak \& Erkut, 2005; Atan \& Maden, 2005; Girginer, 2008; Akkaya \& Demireli, 2010). However, it must be noted that there is limited use of AHP among these techniques.

Some credit rating studies using AHP may be summarised as follows: Babic and Plazibat (1998) studied the ranking of enterprises according to the achieved level of business efficiency using the PROMETHEE method and AHP. The PROMETHEE method is used for the final ranking, while AHP is used to determine the importance of criteria. The main purpose of the work was to present the methodology, which at any time (with the available business indicators) can provide information about the financial standing of a particular enterprise and the profitability of conducting business with such an enterprise.

Chen and Chiou (1999) developed a fuzzy credit-rating approach to address the problem arising from the credit-rating table currently used in Taiwan. The credit-rating criteria are modeled in a tree hierarchical decision structure consisting of several "basic" hierarchical structures. The membership degrees of the five rating levels for describing the final evaluation results may provide loan officers with more valuable information for making decisions. Loan officers at some banks in Southern Taiwan currently treat the proposed approach as a decision support system for commercial loans.

İc and Yurdakul (2000) developed a credit rating model using AHP. Their model, which evaluates both qualitative and quantitative factors, gives the result as a general credit score. This is used in the literature and in practice and includes the subjective creditworthiness of the firms, the status of their sector, the collateral surety, and, in particular, the principles of financial analysis used.

Atan et al. (2004) evaluated the process of decision-making in favor of the approval or refusal of the credit demand and the amount of the loan with AHP. They determined the credit scores of those demanding credit in four main categories: financial status, indemnification, status of employment, and personal information.

Atan and Maden (2005) aimed to measure credibility with AHP in the evaluation of persons and bodies demanding credit from a bank. To that end, they determined the credit scores of individuals and bodies demanding credit categorised by morality, income status, and the results of the credit 
register office's search screen, cosigner, employment status, personal information, and assets.

Girginer (2008) determined the criteria considered by private and public banks in the evaluation of commercial credit demands. In the study, a hierarchical model consisting of four main criteria (financial, managerial, sectoral, and intelligence) was evaluated with AHP in two models of private and public banks, with a comparison between the results of these two models. It was determined that the public bank attached weight to the financial structure of the firm, whereas the private bank attached weight to the managerial structure and intelligence acquired in the evaluation of credit applications.

$\mathrm{Xu}$ and Zhang (2009) developed a new method of credit evaluation based on AHP, presenting set pair analysis (SPA) to determine the credibility of electronic commerce participants. By combining the identity discrepancy contrary analytical thinking of SPA with AHP and applying the online credit evaluations, they built a dynamic model that took account of the uncertainty interference, treating qualitative and quantitative indicators. According to their findings, their model could provide a better explanation of the current credit evaluation scores and the information on potential scores, thus obtaining a true credit evaluation.

Akkaya and Demireli (2010) developed a model for the evaluation of weights for the financial ratios used as the basic performance indicator of the firms during the process of crediting the credit agency by using AHP. At the end of the study, it was found that the credit agencies consider the turnover rate of activity the most important and the financial structure the least important.

As seen in the literature review, many studies have been conducted on the evaluation of both personal and commercial loan applications. However, there are few studies on the evaluation of credit demands in which AHP is used. No studies were found on the evaluation of credit demands using GRA. Further, there was no study in which the firms were ranked by their priorities by obtaining the weights of criteria and sub-criteria applying AHP. Considering this gap in the literature, AHP and GRA, which is another multi-criteria decision-making technique, has been used to determine the decisions made by banks granting commercial credit. The objective of this study is to make the selection of the most appropriate firm with GRA by defining the priorities and criteria with AHP, which must be evaluated with and considered in the commercial credit demand of the firms. It is expected that this study and its results will be beneficial to the parties in the study when they are required to make a selection decision like this.

On the other hand, when considering the criteria and sub-criteria affecting the commercial credit decision by banks, the reason for using AHP in this application is to evaluate numerous qualitative and quantitative criteria together. This means considering all the criteria simultaneously and developing priority values for pairwise comparisons, criteria, sub-criteria and alternatives. The reason for using GRA in the application is to provide a comparison with lesser data according to other statistical methods, and to facilitate digitisation of the obscurities in the commercial credit decisions. Further, the reason for putting GRA sorting before that of AHP is due to existing a sharing in AHP, but existing optimum sorting by evolvement out of gray relation grades in GRA.

\section{Materials and methods}

This study used the AHP proposed by Saaty (1980) and GRA to select the most appropriate firm that applied for a commercial loan. AHP provides an optimal solution considering both qualitative and quantitative aspects of a decision. Another advantage of AHP is that it reduces the level of comparison from a large number of factors to a few. GRA provides optimal decision-making with relational coefficient matrices, which are used to compute the weights of the criteria. The objective of this study is to apply the AHP and GRA for the selection of the best firm. The proposed method comprises two parts. The first part employs the AHP to determine the weights of the criteria. The second part applies GRA to rank the alternatives and select the best firm.

\subsection{Determining the weights of criteria using AHIP}

As a decision-making method that transforms a complex multi-criteria decision problem into a hierarchy (Saaty, 1994; Tung \& Tang, 1998; Lee et al., 1999; Macharis et al., 2004), AHP is a 
measurement theory that prioritises according to groups of decision-makers. The assumption that there is no interdependence among the sub-criteria should be firmly emphasised in determining the prospective upper-level criterion. AHP incorporates the evaluations of all the decision-makers into a final decision (Javalgi, Armacost \& Husseini, 1989; Forman \& Peniwati, 1998; Chou, Lin, Lin, Chou \& Huang, 2004; Chang, Wu, Lin \& Chen, 2007; Wu, Shih \& Chan, 2008), without having to elicit their utility functions on subjective and objective criteria by pair-wise comparisons of the alternatives (Saaty, 1990; Lipovetsky, 1996; Saaty, 2000; Altuzarra, Maria, Jimenez \& Salvador, 2007). The AHP framework is constructed in the form of a matrix, and a local priority vector may be derived as an estimate of relative importance associated with the elements (or components) under comparison by solving the following equations:

$$
A . w=\lambda_{\max } . w
$$

where $\mathrm{A}$ is the matrix of pair-wise comparison, $\mathrm{w}$ is the eigenvector, and $\lambda_{\max }$ is the largest eigenvalue of $\mathrm{A}$.

Saaty (1980) proposed utilising the consistency index (CI) and consistency ratio (CR). To verify the consistency of the comparison matrix, CI and CR are defined as follows:

$$
\begin{aligned}
& C I=\frac{\lambda_{\max }-n}{n-1} \\
& C R=\frac{C I}{R I}
\end{aligned}
$$

where RI represents the average consistency index over several random entries of same-order reciprocal matrices. If $\mathrm{CR} \leq 0.1$, the estimate is accepted or else a new comparison matrix is solicited until $\mathrm{CR} \leq 0.1$.

In the study, the hierarchical structure of the commercial credit demand evaluation problem was established by determining the target, the criteria and the sub-criteria of the problem, with opinions from three experts (a bank manager at a public bank and two commercial credit service officials at a private bank), appointed in their relevant subject fields at a public and a private bank. The points in the problem related to four firms operating in the same sector. The hierarchical structure of the problem is given in Figure 1. Five main criteria (financial structure, partners and managerial structure, sales and marketing structure, sectoral structure, and firm morality and intelligence), each one of which also includes sub-criteria, were taken into consideration during the establishment of the hierarchical structure.

Another significant stage of the AHP decision process consists of obtaining pairwise comparison values following the establishment of the problem's hierarchical structure. A questionnaire was prepared on the basis of a pairwise comparison matrix established for each level of the hierarchy provided in Figure 1. The pairwise comparisons between the alternatives, criteria, and sub-criteria in the questionnaire were judged in accordance with their levels of priority by using the scale developed by Saaty (Saaty, 1980). Three experts, whose opinions were obtained during the establishment of the problem's hierarchical structure, were also the participants who conducted the pairwise comparisons. While the geometrical means of judgment by the two experts from the public bank were calculated as final priority values for the relevant bank, the judgments by the bank manager from the public bank were evaluated by a single decision-maker for the public bank.

After pairwise comparisons were conducted for all of the criteria and sub-criteria, the relative priority values of each criterion and sub-criterion, as well as their values relative to alternatives, were obtained separately for the public and private banks. They are shown below in Table 1 and Table 2 . 
Figure 1

Hierarchical structure of problem for the evaluation of credit demand

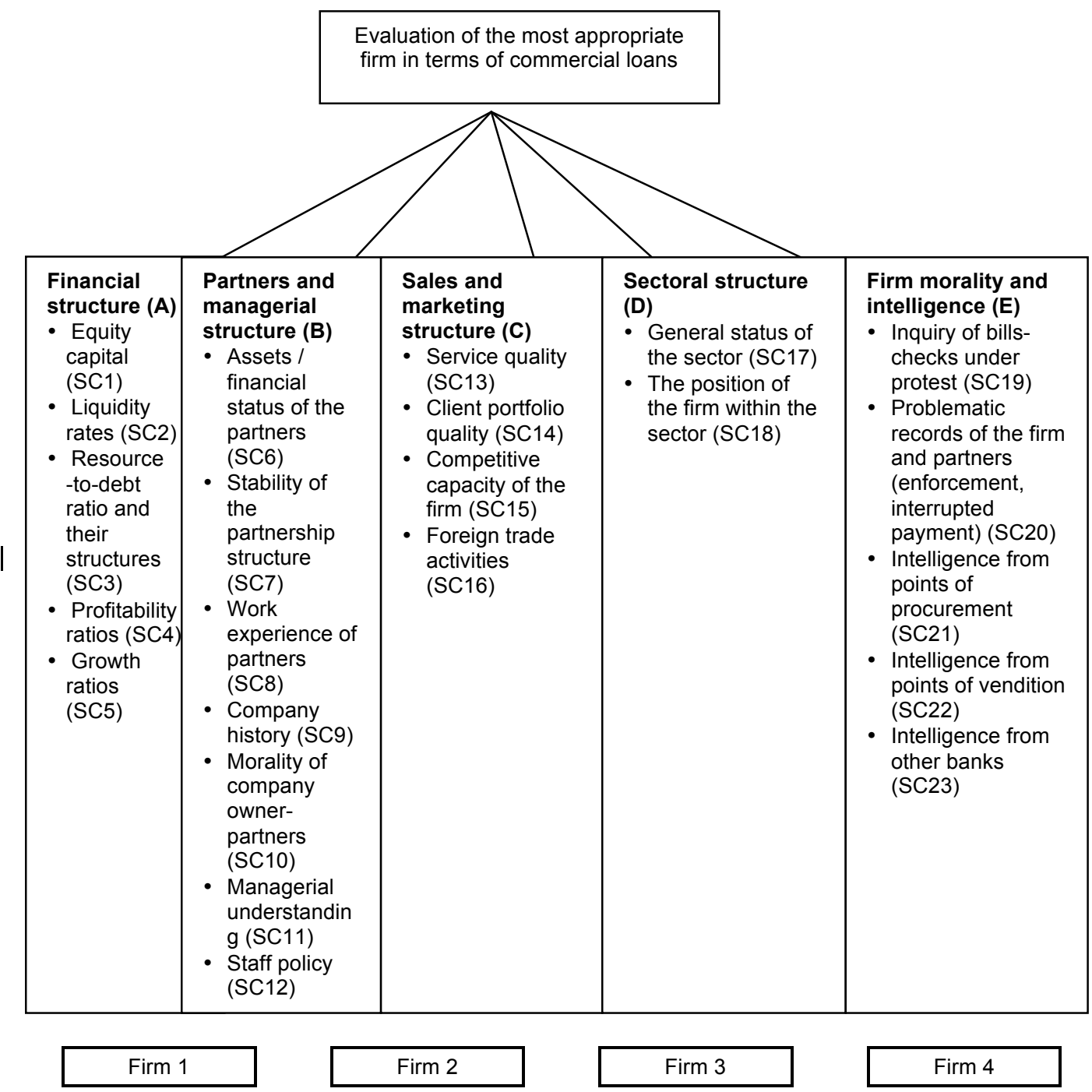

After pairwise comparisons were conducted for all of the criteria and sub-criteria, the relative priority values of each criterion and sub-criterion, as well as their values relative to alternatives, were obtained separately for the public and private banks. They are shown below in Table 1 and Table 2.

Table 2 shows that the criterion with the highest priority for the public bank in the process of commercial credit demand evaluation is the firm's morality and intelligence (46.8 per cent), followed by the financial structure $(25.3$ per cent) and the partners and the managerial structure (14.7 per cent). The sales and marketing structure ( 8.1 per cent) and the sectoral structure (5.1 per cent) rank hold the lowest priority for the public bank evaluating commercial credit demand.

Because the firm's morality and intelligence is the main criterion for public banks, one of the sub-criteria of this main criterion with the highest relative priority is the inquiry about the billschecks under protest (0.309), which was followed by the problematic records of the firm and partners (0.260), and intelligence from other banks (0.235). Intelligence from points of vendition (0.064) ranks last. When the main criterion for the financial structure is considered, the relative priority value of the sub-criterion of equity capital is $(0.466)$ higher than the other sub-criteria. 
This sub-criterion is followed by the resources-to-debt ratio and their structures with the priority level of 0.213 , and the priority levels of the profitability and growth ratios of the bank are only 0.040 and 0.084 . The sub-criteria with the highest priority for the main criterion of the partners and managerial structure are the partners' work experience and work history (0.229) and the morality of the company owner-partners $(0.224)$. The sub-criterion with the lowest priority is that of the staff policies, with a priority level of 0.040 . The sub-criterion with the highest priority in the main criterion of the sales and marketing structure is the firm's competitive capacity (0.419). This sub-criterion is followed by the client portfolio quality and service quality respectively. The foreign trade activities of the firm did not stand out as an important sub-criterion for the public bank. The general status of the sector $(0.833)$ for the sectoral structure with the lowest priority among the main criteria is regarded as more significant than the position of the firm within the sector (0.167).

Table 1

AHP result matrix for public bank

\begin{tabular}{|c|c|c|c|c|c|}
\hline Main criteria & $\begin{array}{ll} & \text { Alternatives } \\
\text { Sub-criteria } & \end{array}$ & Firm 1 & Firm 2 & Firm 3 & Firm 4 \\
\hline \multirow{5}{*}{$\begin{array}{c}\text { Financial structure } \\
(0.253)\end{array}$} & SC1 $(0.466)$ & 0.560 & 0.249 & 0.095 & 0.095 \\
\hline & SC2 (0.198) & 0.565 & 0.262 & 0.118 & 0.055 \\
\hline & SC3 (0.213) & 0.396 & 0.396 & 0.117 & 0.091 \\
\hline & SC4 (0.084) & 0.360 & 0.399 & 0.159 & 0.081 \\
\hline & SC5 (0.040) & 0.399 & 0.360 & 0.159 & 0.081 \\
\hline \multirow{7}{*}{$\begin{array}{l}\text { Partners and } \\
\text { management } \\
\text { structure } \\
(0.147)\end{array}$} & SC6 (0.111) & 0.399 & 0.360 & 0.159 & 0.081 \\
\hline & SC7 (0.202) & 0.250 & 0.250 & 0.250 & 0.250 \\
\hline & SC8 (0.229) & 0.383 & 0.383 & 0.175 & 0.060 \\
\hline & $\operatorname{SC9}(0.130)$ & 0.390 & 0.390 & 0.152 & 0.068 \\
\hline & SC10 $(0.224)$ & 0.390 & 0.390 & 0.152 & 0.068 \\
\hline & SC11 (0.065) & 0.368 & 0.368 & 0.169 & 0.096 \\
\hline & SC12 (0.040) & 0.399 & 0.360 & 0.159 & 0.081 \\
\hline \multirow{4}{*}{$\begin{array}{c}\text { Sales and } \\
\text { marketing } \\
\text { structure } \\
(0.081)\end{array}$} & $\operatorname{SC13}(0.221)$ & 0.300 & 0.300 & 0.300 & 0.100 \\
\hline & SC14 (0.312) & 0.300 & 0.300 & 0.300 & 0.100 \\
\hline & SC15 (0.419) & 0.399 & 0.360 & 0.159 & 0.081 \\
\hline & SC16 (0.048) & 0.250 & 0.250 & 0.250 & 0.250 \\
\hline \multirow{2}{*}{$\begin{array}{c}\text { Sectoral structure } \\
(0.051)\end{array}$} & SC17 (0.833) & 0.300 & 0.300 & 0.300 & 0.100 \\
\hline & SC18 $(0.167)$ & 0.300 & 0.300 & 0.300 & 0.100 \\
\hline \multirow{5}{*}{$\begin{array}{c}\text { Firm morality and } \\
\text { intelligence } \\
(0.468)\end{array}$} & SC19 (0.309) & 0.390 & 0.390 & 0.152 & 0.068 \\
\hline & SC20 (0.260) & 0.300 & 0.300 & 0.300 & 0.100 \\
\hline & SC21 (0.132) & 0.300 & 0.300 & 0.300 & 0.100 \\
\hline & SC22 (0.064) & 0.250 & 0.250 & 0.250 & 0.250 \\
\hline & SC23 (0.235) & 0.383 & 0.383 & 0.175 & 0.060 \\
\hline
\end{tabular}

Table 2 shows that the main criterion with the highest priority for the private bank in evaluating commercial credit demand is firm morality and intelligence (39.4 per cent), as in the case of the public bank, which is followed by the main criteria of the partners and managerial structure (34.5 per cent), and the financial structure (17.2 per cent). When compared with the public bank in terms of priority levels, it is noticed that only the order of the second and third main criteria changed. It is clear that the main criteria of the sales and marketing structure (5.1 per cent) and the sectoral structure (3.9 per cent) are among those ranked last in terms of the priority level for private banks evaluating commercial credit demand. 
Table 2

AHP result matrix for private bank

\begin{tabular}{|c|c|c|c|c|c|}
\hline Main criteria & $\begin{array}{ll} & \text { Alternatives } \\
\text { Sub-Criteria } & \end{array}$ & Firm 1 & Firm 2 & Firm 3 & Firm 4 \\
\hline \multirow{5}{*}{$\begin{array}{r}\text { Financial } \\
\text { structure } \\
(0.172)\end{array}$} & SC1 (0.194) & 0.062 & 0.487 & 0.383 & 0.068 \\
\hline & SC2 (0.227) & 0.054 & 0.682 & 0.161 & 0.102 \\
\hline & SC3 (0.303) & 0.667 & 0.047 & 0.119 & 0.167 \\
\hline & SC4 (0.201) & 0.044 & 0.538 & 0.200 & 0.217 \\
\hline & SC5 (0.076) & 0.076 & 0.572 & 0.179 & 0.172 \\
\hline \multirow{7}{*}{$\begin{array}{l}\text { Partners and } \\
\text { management } \\
\text { structure } \\
(0.345)\end{array}$} & SC6 (0.089) & 0.045 & 0.635 & 0.158 & 0.162 \\
\hline & SC7 (0.149) & 0.039 & 0.467 & 0.327 & 0.166 \\
\hline & SC8 (0.137) & 0.049 & 0.695 & 0.185 & 0.071 \\
\hline & SC9 $(0.084)$ & 0.044 & 0.471 & 0.336 & 0.150 \\
\hline & SC10 (0.441) & 0.036 & 0.585 & 0.238 & 0.141 \\
\hline & SC11 (0.055) & 0.045 & 0.666 & 0.222 & 0.066 \\
\hline & SC12 (0.047) & 0.110 & 0.433 & 0.303 & 0.154 \\
\hline \multirow{4}{*}{$\begin{array}{c}\text { Sales and } \\
\text { marketing } \\
\text { structure } \\
(0.051)\end{array}$} & SC13 (0.125) & 0.127 & 0.472 & 0.228 & 0.173 \\
\hline & SC14 (0.118) & 0.048 & 0.673 & 0.183 & 0.095 \\
\hline & SC15 (0.268) & 0.045 & 0.650 & 0.187 & 0.118 \\
\hline & SC16 (0.489) & 0.250 & 0.250 & 0.250 & 0.250 \\
\hline \multirow{2}{*}{$\begin{array}{l}\text { Sectoral structure } \\
(0.039)\end{array}$} & SC17 (0.500) & 0.120 & 0.441 & 0.257 & 0.182 \\
\hline & SC18 $(0.500)$ & 0.052 & 0.674 & 0.176 & 0.098 \\
\hline \multirow{5}{*}{$\begin{array}{l}\text { Firm morality and } \\
\text { intelligence } \\
(0.394)\end{array}$} & $\operatorname{SC19}(0.216)$ & 0.250 & 0.250 & 0.250 & 0.250 \\
\hline & SC20 $(0.400)$ & 0.112 & 0.471 & 0.208 & 0.208 \\
\hline & SC21 (0.097) & 0.114 & 0.463 & 0.259 & 0.164 \\
\hline & SC22 (0.097) & 0.109 & 0.412 & 0.284 & 0.195 \\
\hline & SC23 (0.191) & 0.046 & 0.574 & 0.247 & 0.134 \\
\hline
\end{tabular}

The sub-criterion with the highest priority among the sub-criteria of the main criteria for firm morality and intelligence for the private bank is the problematic records of the firm and partners $(0.400)$, followed by the inquiry into bills-checks under protest $(0.216)$ and intelligence from other banks (0.191). The sub-criterion of intelligence from points of procurement and vendition (0.097) rank last. As for the main criterion of partners and managerial structure, the sub-criterion with the highest priority level was the morality of the company's owner-partners (0.441). This sub-criterion is followed by stability in the partnership structure $(0.149)$ and the work experience of the company's owner-partners (0.137). The company history, managerial understanding, and staff policy stood out as sub-criteria with very low priority levels. Considering the main criterion of the financial structure, the sub-criterion of the resources-to-debt ratio and their structures has the highest priority $(0.303)$. However, the fact that the growth ratios have a priority of 0.076 was interesting. Contrary to the public bank, the sub-criterion with the highest priority of the main criteria of the sales and marketing structure was defined as foreign trade activities (0.489). The client portfolio quality has the lowest priority for this bank (0.118). In the criteria of the sectoral structure with the lowest priority among the main criteria, the general status of the sector $(0.500)$ and the position of the firm within the sector $(0.500)$ have equal priority rankings.

\subsection{Determining the best firm using GRA}

Deng (1989) introduced "The grey system theory" to supplement the limitations of using traditional statistical methods. Grey system analysis is useful for capturing the correlations between the reference factor and other factors that can be compared within a system (Deng, 1989). Grey system theory is unlike the traditional statistics analysis handling the relation between variables. One of the features of GRA is that a qualitative and quantitative relationship may both 
be identified among the complex factors with insufficient information relative to conventional statistical methods. Under such conditions, the results generated by conventional statistical techniques may not be acceptable without sufficient data to achieve the desired confidence levels. In contrast, grey system theory may be used to identify major correlations among the factors of a system with a relatively small amount of data. Because of these features, GRA has been extensively applied in many contexts, such as financial institutions, hospitals, banks and airline firms.

The procedure for calculating the GRA is as follows (Wu, Lin \& Tsai, 2010):

\section{Calculate the Grey Relation Grade}

Let $\mathrm{X}_{0}$ be the referential series with $\mathrm{k}$ entities (or criteria) of $\mathrm{X}_{1}, \mathrm{X}_{2}, \ldots \mathrm{X}_{\mathrm{i}}, \ldots \mathrm{X}_{\mathrm{N}}$ (or $\mathrm{N}$ measurement criteria). Then,

$$
\begin{gathered}
X_{0}=\left\{\mathrm{x}_{0}(1), \mathrm{x}_{0}(2), \ldots, \mathrm{x}_{0}(\mathrm{k})\right\}, \\
\mathrm{X}_{1}=\left\{\mathrm{x}_{1}(1), \mathrm{x}_{1}(2), \ldots, \mathrm{x}_{1}(\mathrm{k})\right\}, \\
\cdot \\
\mathrm{X}_{\mathrm{i}}=\left\{\mathrm{x}_{\mathrm{i}}(1), \mathrm{x}_{\mathrm{i}}(2), \ldots, \mathrm{x}_{\mathrm{i}}(\mathrm{k})\right\}, \\
\cdot \\
\cdot \\
\mathrm{X}_{\mathrm{N}}=\left\{\mathrm{x}_{\mathrm{N}}(1), \mathrm{x}_{\mathrm{N}}(2), \ldots, \mathrm{x}_{\mathrm{N}}(\mathrm{k})\right\}
\end{gathered}
$$

The grey relation coefficient between the compared series $X_{i}$ and the referential series of $X_{0}$ at the $\mathrm{j}$-th entity is defined as follows:

$$
\gamma_{0 i}(j)=\frac{\Delta \min +\Delta \max }{\Delta_{0 i}(j)+\Delta \max }
$$

where $\Delta_{0 i}(j)$ is the absolute value of difference between $\mathrm{X}_{0}$ and $\mathrm{X}_{\mathrm{i}}$ at the $\mathrm{j}$-th entity, that is, $\Delta_{0 i}(j)=\left|x_{0}(j)-x_{i}(j)\right|$, and $\Delta_{\max }=\operatorname{Max}_{i} \max _{j} \Delta_{0 i}(j), \Delta_{\min }=\operatorname{Min}_{i} \min _{j} \Delta_{0 i}(j)$ The grey relational grade $(\mathrm{GRG})$ for the series of $\mathrm{X}_{\mathrm{i}}$ is given as follows:

$$
\Gamma_{0 i}=\sum_{j=1}^{K} w_{j} \gamma_{0 i}(j)
$$

where $\mathrm{w}_{\mathrm{j}}$ is the weight of the $\mathrm{j}$-th entity. If it is not necessary to apply the weight, take $\omega_{j}=\frac{1}{K}$ as an average.

\section{Data normalisation (or data dimensionless)}

Before calculating the grey relation coefficients, the data series may be treated, based on the following three types of situations and the linearity of data normalisation, to avoid distorting the normalised data (Hsia \& Wu, 1997).

These are:

1) Benefit target: Upper-bound effectiveness measuring (i.e., larger is better)

$$
x_{i}^{*}(j)=\frac{x_{i}(j)-\min _{j} x_{i}(j)}{\max _{j} x_{i}(j)-\min _{j} x_{i}(j)}
$$

2) Cost target: Lower-bound effectiveness measuring (i.e., smaller is better)

$$
x_{i}^{*}(j)=\frac{\max _{j} x_{i}(j)-x_{i}(j)}{\max _{j} x_{i}(j)-\min _{j} x_{i}(j)}
$$

3) Medium target: Moderate effectiveness measuring (i.e., nominal is best) 
If $\min _{j} x_{i}(j) \leq x_{o b}(j) \leq \max _{j} x_{i}(j)$, then

$$
x_{i}^{*}(j)=\frac{\left|x_{i}(j)-x_{o b}(j)\right|}{\max _{j} x_{i}(j)-\min _{j} x_{i}(j)}
$$

if $\max _{j} x_{i}(j) \leq x_{o b}(j)$, then

$$
\begin{array}{r}
x_{i}^{*}(j)=\frac{x_{i}(j)-\min _{j} x_{i}(j)}{x_{o b}(j)-\min _{j} x_{i}(j)} \\
\text { if } x_{o b}(j) \leq \min _{j} x_{i}(j), \text { then } \\
x_{i}^{*}(j)=\frac{\max _{j} x_{i}(j)-x_{i}(j)}{\max _{j} x_{i}(j)-x_{o b}(j)}
\end{array}
$$

where $x_{o b}(j)$ is the objective value of entity $j$.

The GRA calculation process explained above has been applied as shown below in steps in accordance with the purpose of the study.

Step 1: Establishing the decision making matrix

The weight is estimated for five experts, with each respondent using Saaty's relative importance scale and averaging their scale to assess candidates, then establishing a decision-making matrix, as

\begin{tabular}{|c|c|c|c|c|c|}
\hline \multirow{2}{*}{ Sub-criteria } & \multicolumn{5}{|c|}{ Firms } \\
\hline & Reference & Firm1 & Firm2 & Firm3 & Firm4 \\
\hline SC1 & 0.560 & 0.560 & 0.249 & 0.095 & 0.095 \\
\hline SC2 & 0.565 & 0.565 & 0.262 & 0.118 & 0.055 \\
\hline SC3 & 0.396 & 0.396 & 0.396 & 0.117 & 0.091 \\
\hline SC4 & 0.399 & 0.360 & 0.399 & 0.159 & 0.081 \\
\hline SC5 & 0.399 & 0.399 & 0.360 & 0.159 & 0.081 \\
\hline SC6 & 0.399 & 0.399 & 0.360 & 0.159 & 0.081 \\
\hline SC7 & 0.250 & 0.250 & 0.250 & 0.250 & 0.250 \\
\hline SC8 & 0.383 & 0.383 & 0.383 & 0.175 & 0.060 \\
\hline SC9 & 0.390 & 0.390 & 0.390 & 0.152 & 0.068 \\
\hline SC10 & 0.390 & 0.390 & 0.390 & 0.152 & 0.068 \\
\hline SC11 & 0.368 & 0.368 & 0.368 & 0.169 & 0.096 \\
\hline SC12 & 0.399 & 0.399 & 0.360 & 0.159 & 0.081 \\
\hline SC13 & 0.300 & 0.300 & 0.300 & 0.300 & 0.100 \\
\hline SC14 & 0.300 & 0.300 & 0.300 & 0.300 & 0.100 \\
\hline SC15 & 0.399 & 0.399 & 0.360 & 0.159 & 0.081 \\
\hline SC16 & 0.250 & 0.250 & 0.250 & 0.250 & 0.250 \\
\hline SC17 & 0.300 & 0.300 & 0.300 & 0.300 & 0.100 \\
\hline SC18 & 0.300 & 0.300 & 0.300 & 0.300 & 0.100 \\
\hline SC19 & 0.390 & 0.390 & 0.390 & 0.152 & 0.068 \\
\hline SC20 & 0.390 & 0.390 & 0.300 & 0.300 & 0.100 \\
\hline SC21 & 0.300 & 0.300 & 0.300 & 0.300 & 0.100 \\
\hline SC22 & 0.250 & 0.250 & 0.250 & 0.250 & 0.250 \\
\hline SC23 & 0.383 & 0.383 & 0.383 & 0.175 & 0.060 \\
\hline
\end{tabular}
shown in Table 3.

Table 3a

The decision making matrix for public bank judgments 
Table 3b

The decision making matrix for private bank judgments

\begin{tabular}{|c|c|c|c|c|c|}
\hline \multirow{2}{*}{ Sub-criteria } & \multicolumn{5}{|c|}{ Firms } \\
\hline & Reference & Firm1 & Firm2 & Firm3 & Firm4 \\
\hline SC1 & 0.487 & 0.062 & 0.487 & 0.383 & 0.068 \\
\hline SC2 & 0.682 & 0.054 & 0.682 & 0.161 & 0.102 \\
\hline SC3 & 0.667 & 0.667 & 0.047 & 0.119 & 0.167 \\
\hline SC4 & 0.538 & 0.044 & 0.538 & 0.200 & 0.217 \\
\hline SC5 & 0.572 & 0.076 & 0.572 & 0.179 & 0.172 \\
\hline SC6 & 0.635 & 0.045 & 0.635 & 0.158 & 0.162 \\
\hline SC7 & 0.467 & 0.039 & 0.467 & 0.327 & 0.166 \\
\hline SC8 & 0.695 & 0.049 & 0.695 & 0.185 & 0.071 \\
\hline SC9 & 0.471 & 0.044 & 0.471 & 0.336 & 0.150 \\
\hline SC10 & 0.585 & 0.036 & 0.585 & 0.238 & 0.141 \\
\hline SC11 & 0.666 & 0.045 & 0.666 & 0.222 & 0.066 \\
\hline SC12 & 0.433 & 0.110 & 0.433 & 0.303 & 0.154 \\
\hline SC13 & 0.472 & 0.127 & 0.472 & 0.228 & 0.173 \\
\hline SC14 & 0.673 & 0.048 & 0.673 & 0.183 & 0.095 \\
\hline SC15 & 0.650 & 0.045 & 0.650 & 0.187 & 0.118 \\
\hline SC16 & 0.250 & 0.250 & 0.250 & 0.250 & 0.250 \\
\hline SC17 & 0.441 & 0.120 & 0.441 & 0.257 & 0.182 \\
\hline SC18 & 0.674 & 0.052 & 0.674 & 0.176 & 0.098 \\
\hline SC19 & 0.250 & 0.250 & 0.250 & 0.250 & 0.250 \\
\hline SC20 & 0.471 & 0.112 & 0.471 & 0.208 & 0.208 \\
\hline SC21 & 0.463 & 0.114 & 0.463 & 0.259 & 0.164 \\
\hline SC22 & 0.412 & 0.109 & 0.412 & 0.284 & 0.195 \\
\hline SC23 & 0.574 & 0.046 & 0.574 & 0.247 & 0.134 \\
\hline & & & & & \\
\hline
\end{tabular}

The twenty three sub-criteria accord with the statement "the-larger-the-better", because each of them is compared according to their importance. Accordingly, the referential series may be described as $X_{0}=(0.487, \ldots, 0.574)$. The candidates (alternatives) are $X_{1}($ Firm 1$), X_{2}\left(\right.$ Firm2), $X_{3}$ (Firm3) and $\mathrm{X}_{4}$ (Firm4).

Step 2: Normalising data

After establishing a decision-making matrix, its established referential series may be described as $\mathrm{X}_{0}=\{1.00,1.00,1.00, \ldots, 1.00\}$. The statistical programs are $\mathrm{X}_{1}, \mathrm{X}_{2}, \mathrm{X}_{3}$ and $\mathrm{X}_{4}$. The data are normalised for 21 sub-criteria with equation (6). Table $4 \mathrm{a}$ and Table $4 \mathrm{~b}$ summarise the normalisation data.

Table 4a

Summary of normalisation data for public bank

\begin{tabular}{|c|c|c|c|c|c|}
\hline \multirow{2}{*}{ Sub-criteria } & \multicolumn{5}{|c|}{ Firms } \\
\hline & Reference $\left(X_{0}\right)$ & Firm1 $\left(X_{1}\right)$ & Firm2 $\left(X_{2}\right)$ & Firm3 $\left(X_{3}\right)$ & Firm4 $\left(X_{4}\right)$ \\
\hline SC1 & 1.00 & 1.00 & 0.328 & 0.00 & 0.00 \\
\hline SC2 & 1.00 & 1.00 & 0.406 & 0.124 & 0.00 \\
\hline $\mathrm{SC} 3$ & 1.00 & 1.00 & 1.00 & 0.085 & 0.00 \\
\hline SC4 & 1.00 & 0.877 & 1.00 & 0.245 & 0.00 \\
\hline SC5 & 1.00 & 1.00 & 0.877 & 0.245 & 0.00 \\
\hline SC6 & 1.00 & 0.00 & 0.877 & 0.245 & 0.00 \\
\hline SC7 & 0.00 & 0.00 & 0.00 & 0.00 & 0.00 \\
\hline SC8 & 1.00 & 1.00 & 1.00 & 0.356 & 0.00 \\
\hline
\end{tabular}




\begin{tabular}{|c|c|c|c|c|c|}
\hline \multirow{2}{*}{ Sub-criteria } & \multicolumn{5}{|c|}{ Firms } \\
\hline & Reference $\left(X_{0}\right)$ & $\operatorname{Firm1}\left(X_{1}\right)$ & Firm2 $\left(X_{2}\right)$ & Firm3 $\left(X_{3}\right)$ & Firm4 $\left(X_{4}\right)$ \\
\hline SC9 & 1.00 & 1.00 & 1.00 & 0.261 & 0.00 \\
\hline SC10 & 1.00 & 1.00 & 1.00 & 0.261 & 0.00 \\
\hline SC11 & 1.00 & 1.00 & 1.00 & 0.264 & 0.00 \\
\hline SC12 & 1.00 & 1.00 & 0.877 & 0.245 & 0.00 \\
\hline SC13 & 1.00 & 1.00 & 1.00 & 1.00 & 0.00 \\
\hline SC14 & 1.00 & 1.00 & 1.00 & 1.00 & 0.00 \\
\hline SC15 & 1.00 & 1.00 & 0.877 & 0.245 & 0.00 \\
\hline SC16 & 0.00 & 0.00 & 0.00 & 0.00 & 0.00 \\
\hline SC17 & 1.00 & 1.00 & 1.00 & 1.00 & 0.00 \\
\hline SC18 & 1.00 & 1.00 & 1.00 & 1.00 & 0.00 \\
\hline SC19 & 1.00 & 1.00 & 1.00 & 0.261 & 0.00 \\
\hline SC20 & 1.00 & 1.00 & 1.00 & 1.00 & 0.00 \\
\hline SC21 & 1.00 & 1.00 & 1.00 & 1.00 & 0.00 \\
\hline SC22 & 0.00 & 0.00 & 0.00 & 0.00 & 0.00 \\
\hline $\mathrm{SC} 23$ & 1.00 & 1.00 & 1.00 & 0.356 & 0.00 \\
\hline
\end{tabular}

Table 4b

Summary of normalisation data for private bank

\begin{tabular}{|c|c|c|c|c|c|}
\hline \multirow{2}{*}{ Sub-criteria } & \multicolumn{5}{|c|}{ Firms } \\
\hline & Reference $\left(\mathbf{X}_{0}\right)$ & $\operatorname{Firm1}\left(\mathrm{X}_{1}\right)$ & $\operatorname{Firm2}\left(X_{2}\right)$ & Firm3( $\left.X_{3}\right)$ & Firm4( $\left.X_{4}\right)$ \\
\hline SC1 & 1.00 & 0.00 & 1.00 & 0.755 & 0.014 \\
\hline SC2 & 1.00 & 0.00 & 1.00 & 0.170 & 0.076 \\
\hline SC3 & 1.00 & 1.00 & 0.00 & 0.184 & 0.193 \\
\hline SC4 & 1.00 & 0.00 & 1.00 & 0.316 & 0.350 \\
\hline SC5 & 1.00 & 0.00 & 1.00 & 0.208 & 0.194 \\
\hline SC6 & 1.00 & 0.00 & 1.00 & 0.192 & 0.198 \\
\hline SC7 & 1.00 & 0.00 & 1.00 & 0.673 & 0.297 \\
\hline SC8 & 1.00 & 0.00 & 1.00 & 0.211 & 0.034 \\
\hline SC9 & 1.00 & 0.00 & 1.00 & 0.684 & 0.248 \\
\hline SC10 & 1.00 & 0.00 & 1.00 & 0.368 & 0.191 \\
\hline SC11 & 1.00 & 0.00 & 1.00 & 0.285 & 0.034 \\
\hline SC12 & 1.00 & 0.00 & 1.00 & 0.598 & 0.136 \\
\hline SC13 & 1.00 & 0.00 & 1.00 & 0.293 & 0.133 \\
\hline SC14 & 1.00 & 0.00 & 1.00 & 0.216 & 0.075 \\
\hline SC15 & 1.00 & 0.00 & 1.00 & 0.235 & 0.121 \\
\hline SC16 & 0.00 & 0.00 & 0.00 & 0.00 & 0.00 \\
\hline SC17 & 1.00 & 0.00 & 1.00 & 0.427 & 0.193 \\
\hline SC18 & 1.00 & 0.00 & 1.00 & 0.199 & 0.074 \\
\hline SC19 & 0.00 & 0.00 & 0.00 & 0.00 & 0.00 \\
\hline SC20 & 1.00 & 0.00 & 1.00 & 0.267 & 0.267 \\
\hline SC21 & 1.00 & 0.00 & 1.00 & 0.415 & 0.143 \\
\hline SC22 & 1.00 & 0.00 & 1.00 & 0.578 & 0.284 \\
\hline SC23 & 1.00 & 0.00 & 1.00 & 0.381 & 0.167 \\
\hline
\end{tabular}

Step 3: Computing absolute values $\left[\Delta_{0 i}(j)\right]$

$\Delta_{0 i}(j)$ is the absolute value of difference $\mathrm{X}_{0}$ (differential series) and $\mathrm{Xi}$ at the $\mathrm{j}$-th sub-criteria. The computed $\Delta_{0 i}(j)$ are displayed in Table $5 \mathrm{a}$ and Table $5 \mathrm{~b}$. 
Table 5a

Absolute values for public bank

\begin{tabular}{|c|c|c|c|c|}
\hline \multirow{2}{*}{ Sub-criteria } & \multicolumn{4}{|c|}{ Firms } \\
\hline & $\operatorname{Firm1}\left(X_{1}\right)$ & $\operatorname{Firm} 2\left(X_{2}\right)$ & Firm3( $\left.X_{3}\right)$ & Firm4 $\left(X_{4}\right)$ \\
\hline SC1 & 0.00 & 0.672 & 1.00 & 1.00 \\
\hline SC2 & 0.00 & 0.594 & 0.876 & 1.00 \\
\hline SC3 & 0.00 & 0.00 & 0.915 & 1.00 \\
\hline SC4 & 0.123 & 0.00 & 0.755 & 1.00 \\
\hline SC5 & 0.00 & 0.123 & 0.755 & 1.00 \\
\hline SC6 & 0.00 & 0.123 & 0.755 & 1.00 \\
\hline SC7 & 1.00 & 1.00 & 1.00 & 1.00 \\
\hline SC8 & 0.00 & 0.00 & 0.644 & 1.00 \\
\hline SC9 & 0.00 & 0.00 & 0.739 & 1.00 \\
\hline SC10 & 0.00 & 0.00 & 0.739 & 1.00 \\
\hline SC11 & 0.00 & 0.00 & 0.736 & 1.00 \\
\hline SC12 & 0.00 & 0.123 & 0.755 & 1.00 \\
\hline SC13 & 0.088 & 0.00 & 0.00 & 1.00 \\
\hline SC14 & 0.00 & 0.00 & 0.00 & 1.00 \\
\hline SC15 & 0.00 & 0.123 & 0.755 & 1.00 \\
\hline SC16 & 1.00 & 1.00 & 1.00 & 1.00 \\
\hline SC17 & 0.00 & 0.00 & 0.00 & 1.00 \\
\hline SC18 & 0.00 & 0.00 & 0.00 & 1.00 \\
\hline SC19 & 0.00 & 0.00 & 0.739 & 1.00 \\
\hline SC20 & 0.00 & 0.00 & 0.00 & 1.00 \\
\hline SC21 & 0.00 & 0.00 & 0.00 & 1.00 \\
\hline SC22 & 1.00 & 1.00 & 1.00 & 1.00 \\
\hline $\mathrm{SC} 23$ & 0.00 & 0.00 & 0.644 & 1.00 \\
\hline
\end{tabular}

Table 5b

Absolute values for private bank

\begin{tabular}{|c|c|c|c|c|}
\hline \multirow{2}{*}{ Sub-criteria } & \multicolumn{4}{|c|}{ Firms } \\
\hline & Firm1 $\left(X_{1}\right)$ & Firm2( $\left.X_{2}\right)$ & $\operatorname{Firm} 3\left(X_{3}\right)$ & Firm4 $\left(X_{4}\right)$ \\
\hline SC1 & 1.00 & 0.00 & 0.245 & 0.986 \\
\hline SC2 & 1.00 & 0.00 & 0.830 & 0.924 \\
\hline SC3 & 0.00 & 1.00 & 0.816 & 0.807 \\
\hline SC4 & 1.00 & 0.00 & 0.684 & 0.650 \\
\hline SC5 & 1.00 & 0.00 & 0.792 & 0.806 \\
\hline SC6 & 1.00 & 0.00 & 0.808 & 0.802 \\
\hline SC7 & 1.00 & 0.00 & 0.327 & 0.703 \\
\hline SC8 & 1.00 & 0.00 & 0.789 & 0.966 \\
\hline SC9 & 1.00 & 0.00 & 0.316 & 0.752 \\
\hline SC10 & 1.00 & 0.00 & 0.632 & 0.809 \\
\hline SC11 & 1.00 & 0.00 & 0.715 & 0.966 \\
\hline SC12 & 1.00 & 0.00 & 0.402 & 0.864 \\
\hline SC13 & 1.00 & 0.00 & 0.707 & 0.867 \\
\hline SC14 & 1.00 & 0.00 & 0.784 & 0.925 \\
\hline SC15 & 1.00 & 0.00 & 0.765 & 0.879 \\
\hline SC16 & 1.00 & 1.00 & 1.00 & 1.00 \\
\hline SC17 & 1.00 & 0.00 & 0.573 & 0.807 \\
\hline SC18 & 1.00 & 0.00 & 0.801 & 0.926 \\
\hline SC19 & 1.00 & 1.00 & 1.00 & 1.00 \\
\hline SC20 & 1.00 & 0.00 & 0.733 & 0.733 \\
\hline SC21 & 1.00 & 0.00 & 0.585 & 0.857 \\
\hline SC22 & 1.00 & 0.00 & 0.422 & 0.716 \\
\hline SC23 & 1.00 & 0.00 & 0.619 & 0.833 \\
\hline
\end{tabular}


Step 4: Computing Grey relation coefficients $\left[\gamma_{0 i}(j)\right]$

The relational coefficients are computed using equation 4 (See Table 6a and Table 6b).

Table 6a

Grey relation coefficients for public bank

\begin{tabular}{|c|c|c|c|c|c|}
\hline \multirow{2}{*}{ Main criteria } & \multirow{2}{*}{$\begin{array}{l}\text { Sub-criteria } \\
\qquad\left(w_{j}\right)\end{array}$} & \multicolumn{4}{|c|}{ Firms } \\
\hline & & $\operatorname{Firm1}\left(\mathrm{X}_{1}\right)$ & $\operatorname{Firm2}\left(X_{2}\right)$ & $\operatorname{Firm} 3\left(X_{3}\right)$ & Firm4( $\left.X_{4}\right)$ \\
\hline \multirow{5}{*}{$(0.579)$} & SC1 (0.523) & 1.00 & 0.427 & 0.333 & 0.333 \\
\hline & SC2 (0.538) & 1.00 & 0.457 & 0.363 & 0.333 \\
\hline & SC3 (0.622) & 1.00 & 1.00 & 0.353 & 0.333 \\
\hline & SC4 (0.633) & 0.802 & 1.00 & 0.398 & 0.333 \\
\hline & SC5 (0.633) & 1.00 & 0.802 & 0.398 & 0.333 \\
\hline \multirow{7}{*}{$(0.621)$} & SC6 (0.633) & 1.00 & 0.802 & 0.398 & 0.333 \\
\hline & SC7 (0.333) & 0.333 & 0.333 & 0.333 & 0.333 \\
\hline & SC8 (0.693) & 1.00 & 1.00 & 0.437 & 0.333 \\
\hline & SC9 $(0.684)$ & 1.00 & 1.00 & 0.404 & 0.333 \\
\hline & SC10 (0.684) & 1.00 & 1.00 & 0.404 & 0.333 \\
\hline & SC11 (0.685) & 1.00 & 1.00 & 0.405 & 0.333 \\
\hline & SC12 (0.633) & 1.00 & 0.802 & 0.398 & 0.333 \\
\hline \multirow{4}{*}{$(0.658)$} & SC13 (0.833) & 1.00 & 1.00 & 1.00 & 0.333 \\
\hline & SC14 (0.833) & 1.00 & 1.00 & 1.00 & 0.333 \\
\hline & SC15 (0.633) & 1.00 & 0.802 & 0.398 & 0.333 \\
\hline & SC16 (0.333) & 0.333 & 0.333 & 0.333 & 0.333 \\
\hline \multirow{2}{*}{$(0.833)$} & SC17 (0.833) & 1.00 & 1.00 & 1.00 & 0.333 \\
\hline & SC18 (0.833) & 1.00 & 1.00 & 1.00 & 0.333 \\
\hline \multirow{5}{*}{0.703} & SC19 (0.684) & 1.00 & 1.00 & 0.404 & 0.333 \\
\hline & SC20 (0.833) & 1.00 & 1.00 & 1.00 & 0.333 \\
\hline & SC21 (0.833) & 1.00 & 1.00 & 1.00 & 0.333 \\
\hline & SC22 (0.333) & 0.333 & 0.333 & 0.333 & 0.333 \\
\hline & SC23 (0.833) & 1.00 & 1.00 & 1.00 & 0.333 \\
\hline
\end{tabular}

Table 6b

Grey relation coefficients for private bank

\begin{tabular}{|c|c|c|c|c|c|}
\hline \multirow{2}{*}{ Main criteria } & \multirow{2}{*}{$\begin{array}{c}\text { Sub-criteria } \\
\left(w_{\mathrm{j}}\right)\end{array}$} & \multicolumn{4}{|c|}{ Firms } \\
\hline & & $\operatorname{Firm1}\left(\mathrm{X}_{1}\right)$ & Firm2( $\left.X_{2}\right)$ & $\operatorname{Firm} 3\left(X_{3}\right)$ & Firm4( $\left.X_{4}\right)$ \\
\hline \multirow{5}{*}{$(0.539)$} & SC1 (0.584) & 0.333 & 1.00 & 0.671 & 0.336 \\
\hline & SC2 (0.515) & 0.333 & 1.00 & 0.375 & 0.351 \\
\hline & SC3 (0.524) & 1.00 & 0.333 & 0.379 & 0.383 \\
\hline & SC4 (0.547) & 0.333 & 1.00 & 0.422 & 0.435 \\
\hline & SC5 (0.526) & 0.333 & 1.00 & 0.387 & 0.383 \\
\hline \multirow{7}{*}{$(0.549)$} & SC6 $(0.525)$ & 0.333 & 1.00 & 0.382 & 0.384 \\
\hline & SC7 (0.589) & 0.333 & 1.00 & 0.605 & 0.416 \\
\hline & SC8 (0.516) & 0.333 & 1.00 & 0.388 & 0.341 \\
\hline & SC9 (0.586) & 0.333 & 1.00 & 0.613 & 0.399 \\
\hline & SC10 (0.539) & 0.333 & 1.00 & 0.441 & 0.382 \\
\hline & SC11 (0.522) & 0.333 & 1.00 & 0.412 & 0.341 \\
\hline & SC12 (0.563) & 0.333 & 1.00 & 0.554 & 0.366 \\
\hline \multirow{4}{*}{$(0.476)$} & SC13 (0.528) & 0.333 & 1.00 & 0.414 & 0.365 \\
\hline & SC14 (0.518) & 0.333 & 1.00 & 0.389 & 0.351 \\
\hline & SC15 (0.523) & 0.333 & 1.00 & 0.395 & 0.362 \\
\hline & SC16 (0.333) & 0.333 & 0.333 & 0.333 & 0333 \\
\hline \multirow{2}{*}{$(0.532)$} & SC17 (0.546) & 0.333 & 1.00 & 0.466 & 0.383 \\
\hline & SC18 (0.517) & 0.333 & 1.00 & 0.384 & 0.351 \\
\hline
\end{tabular}




\begin{tabular}{|c|c|c|c|c|c|}
\hline \multirow{2}{*}{ Main criteria } & \multirow{2}{*}{$\begin{array}{l}\text { Sub-criteria } \\
\qquad\left(w_{j}\right)\end{array}$} & \multicolumn{4}{|c|}{ Firms } \\
\hline & & $\operatorname{Firm1}\left(\mathrm{X}_{1}\right)$ & $\operatorname{Firm2}\left(X_{2}\right)$ & $\operatorname{Firm} 3\left(X_{3}\right)$ & Firm4 $\left(X_{4}\right)$ \\
\hline \multirow{5}{*}{$(0.504)$} & SC19 (0.333) & 0.333 & 0.333 & 0.333 & 0.333 \\
\hline & SC20 (0.536) & 0.333 & 1.00 & 0.406 & 0.406 \\
\hline & SC21 (0.541) & 0.333 & 1.00 & 0.461 & 0.368 \\
\hline & SC22 (0.572) & 0.333 & 1.00 & 0.542 & 0.411 \\
\hline & SC23 (0.539) & 0.333 & 1.00 & 0.447 & 0.375 \\
\hline
\end{tabular}

Step 5: Computing Grey relation grade

The sub-criteria weights from AHP and GRA are derived using equation (5). Sub-criteria weights (wj) obtained from AHP are shown in the second column in parentheses in Table 6a and Table 6b. Equation 5 was applied for each candidate (firm) as the sum of the grey relation coefficients multiplied by the relative weights of the main criteria. Table $7 \mathrm{a}$ and Table $7 \mathrm{~b}$ summarise these results.

\section{Table 7a}

Grey relation grades $\Gamma_{0 i}=\sum_{j=1}^{K} w_{j} \gamma_{0 i}(j)$ for public bank

\begin{tabular}{|c|c|c|c|}
\hline Firms & $\boldsymbol{\Gamma}_{0 i}$ & $\boldsymbol{\Gamma}_{0 i}$ (with AHP weights) & Rank \\
\hline Firm1 & $90.4 \%$ & $90.8 \%$ & 1 \\
\hline Firm2 & $83.6 \%$ & $83.8 \%$ & 2 \\
\hline Firm3 & $56.9 \%$ & $76.5 \%$ & 3 \\
\hline Firm4 & $33.3 \%$ & $33.7 \%$ & 4 \\
\hline
\end{tabular}

Table $7 b$

Grey relation grades $\Gamma_{0 i}=\sum_{j=1}^{K} w_{j} \gamma_{0 i}(j)$ for private bank

\begin{tabular}{|c|c|c|c|}
\hline Firms & $\boldsymbol{\Gamma}_{0 i}$ & $\boldsymbol{\Gamma}_{0 i}$ (with AHP weights) & Rank \\
\hline Firm1 & $36.2 \%$ & $39.1 \%$ & 4 \\
\hline Firm2 & $91.3 \%$ & $100.0 \%$ & 1 \\
\hline Firm3 & $44.3 \%$ & $50.5 \%$ & 2 \\
\hline Firm4 & $37.2 \%$ & $41.5 \%$ & 3 \\
\hline
\end{tabular}

As shown in Table 7a, Firm 1 (90.4 per cent) is the most appropriate firm for the public bank. Other firms are preferred by the public bank in the following order: Firm 2 (83.6 per cent), Firm 3 (56.9 per cent) and Firm 4 with 33.3 per cent. As shown in Table 7b, Firm 2 (91.3 per cent) is the most appropriate firm for the private bank. Other firms are preferred by the private bank in the following order: Firm 3 (44.3 per cent), Firm 4 (37.2 per cent) and Firm 1, with 36.2 per cent.

\section{Conclusions and discussions}

This study proposes an integrated approach for banks' evaluation and selection of the best firm demanding commercial credit, which employs AHP and GRA in a preference measurement model. The main advantage of this research is that it may be used to accord with both qualitative and quantitative criteria. This study indicates that the AHP and GRA are powerful tools for multicriteria decision-making problems, such as the selection of the most appropriate firm demanding commercial credit. The proposed method consists of two parts. The first part employs the AHP to determine the weights of the criteria. The second part applies GRA to rank alternatives and select the best firm. In this model, new criteria may be added to help to select the best firm. In addition, any new potential firm may be included in the evaluation process. Therefore, in comparison to other models, the proposed model is more flexible, applicable, and effective. 
According to the AHP findings of this study, the main criteria for public banks, listed in order of priority, are firm morality and intelligence, financial structure, partners and management structure, sales and marketing structure, and sectoral structure. The priority ranking of the main criteria for the private banks is as follows: firm morality and intelligence, partners and management structure, financial structure, sales and marketing structure, and sectoral structure. As is observed, the weights and rankings of the main criteria in the evaluation of commercial credit application for both public banks and private banks are almost the same. Morality, which may be defined as the positive impression the party wanting to take a loan makes on the party granting the loan, its honesty and business ethics, and its intelligence. This is the information obtained during market research into the firm. It is prioritised as more important by both of the banks than the other criteria. This situation is a reminder of the question a judge commissioned in the Research Committee of the US Congress directed to the bankers in 1912: "Will banks give credit only to the persons who have money and assets?" J.P. Morgan, whose name was given to one of the largest financial institutions operating today, gave the following answer: "No, morality is the priority." When the judge suspiciously asked the same question again, J.P. Morgan explained: "A person who I don't trust can never get credit from me". This is not a surprising result, considering that sometimes even firms with a good financial status do not reimburse the credit they have received. Accordingly, to minimise the risk of credit, banks do not want to give credit to a firm with low morality, even if it is solvent and has sufficient assets.

The financial structure is considered to be a more important criterion for public banks than for private banks. Therefore, in light of this finding, it may be said that public banks take more notice of economic values than they do of subjective values in credit demand evaluation of the firms. On the other hand, the status of the sector has been the main criterion with the lowest priority for both private and public banks. This finding may be because the sector of a reputable firm, which has made a positive impression on the market with its good financial situation, is relatively less important than its reimbursement of the credit to the bank.

- In the study, the results of the AHP show significant similarities to the results of Girginer (2008). The AHP results of Girginer (2008) stress that public banks place the utmost importance on financial structure, while private banks regard the managerial structure and intelligence as of the highest priority. The status of the sector has been determined as the main criterion with the lowest priority for both of the banks in this study. Whereas financial structure ranks second after firm morality and intelligence according to the AHP results of this study, it is interesting that these two main criteria change rank only in the study by Girginer (2008). The comparison of AHP findings of this study with other studies in the literature was not possible owing to both the inadequacy of the studies using AHP in commercial credit demand evaluation and the difference in hierarchies.

According to the results of GRA performed to determine the most appropriate firm, Firm 1 was chosen as the most appropriate firm for a public bank, followed by Firm 2, Firm 3 and Firm 4. On the other hand, the GRA results for a private bank found Firm 2 to be the most appropriate firm.

Even though the most appropriate firms whose commercial credit demand and weights of the criteria to be covered were determined within the scope of the established hierarchical model by consulting three experts' opinions, these results do not reflect the opinion of all the banking sectors. Although the results of the study are based on the individual considerations of credit evaluation experts from anonymous public and private banks, which are undisclosed for privacy reasons, the results obtained from the study will be helpful for companies applying for credit by enabling them to determine their strengths and weaknesses. Furthermore, the use of the model recommended by the study based on group decision-making and the common considerations by the credit evaluation experts of several public and private banks may facilitate the ability to reach more general results and repeat the study with different criteria and sub-criteria. At the same time, the dependency between criteria, sub-criteria, and alternatives will be considered. For this reason, the criteria weights will be repeated using the Analytic Network Process, ensuring the examination 
of the commercial credit demand evaluation problem in a network. At this point, the application of GRA could be repeated, and the results compared.

\section{References}

ABDOU, H., MASRY, A.E. \& POINTON, J. 2007. On the applicability of credit scoring models in Egyptian banks. Bank and Bank Systems, 2(1):4-20.

AKKAYA, G.C. \& DEMIRELİ, E. 2010. Analitik hiyerarşi süreci ile kredi derecelendirme analizi üzerine bir model önerisi. Ç.Ü. Sosyal Bilimler Enstitüsü Dergisi, 19(1):319-335.

ALBAYRAK, Y.E. \& ERKUT, H. 2005. Banka performans değerlendirmede analitik hiyerarşi süreç yaklaşımı. İTÜ dergisi/d, Mühendislik, 4(6):47-58.

ALTUZARRA, A., MARIA, J., JIMENEZ, M. \& SALVADOR, M. 2007. A Bayesian priorization procedure for AHP-group decision making. European Journal of Operational Research, 182:367-382.

ATAN, M., MADEN, U. \& AKYILDIZ, E. 2004. Analitik hiyerarşi süreci (AHS) kullanımı ile bir bankada kredi taleplerinin değerlendirilmesi, VIII. Ulusal Finans Sempozyumu, 26 - 28 Ekim, İstanbul Teknik Üniversitesi, İTÜ Maçka Kampüsü İşletme Fakültesi.

ATAN, M. \& MADEN, U. 2005. Bireysel ve kurumsal kredibilitenin analitik hiyerarşi süreci ile çözümlenmesi, 4. İstatistik Kongresi, İstatistik Mezunları Derneği ve Türk İstatistik Derneği, 8 - 12 Mayıs, Belek, Antalya.

BABIC, Z. \& PLAZIBAT N. 1998. Ranking of enterprises based on multicriterial analysis. International Journal of Production Economics, 56-57:29-35.

BODUR, Ç. \& TEKER, S. 2005. Ticari firmaların kredi derecelendirmesi: IMKB firmalarına uygulanması, ITÜ Dergisi/b, Sosyal Bilimler, 2(1):25-36.

CHANG, C.W., WU, C.R., LIN, C.T. \& CHEN, H.C. 2007. An application of AHP and sensitivity analysis for selecting the best slicing machines, Computers and Industrial Engineering, 52(3):296-307.

CHEN, L-H. \& CHIOU, T-W. 1999. A fuzzy credit-rating approach for commercial loans: A Taiwan Case. OMEGA, 27(4):407-419.

CHENG, E.W.L., CHIANG, Y.H. \& TANG, B.S. 2007. Alternative approach to credit scoring by DEA: Evaluating borrowers with respect to PFI projects, Building and Environment, 42:1752-1760.

CHOU, T.Y., LIN, W.T., LIN, C.Y., CHOU, W.C. \& HUANG, P.H. 2004. Application of the PROMETHEE Technique to determine depression outlet location and flow direction in DEM. Journal of Hydrology, 287: 49-61.

DENG, J. 1989. Introduction to Grey System Theory. The Journal of Grey System, 1(1):1-24.

FORMAN, E. \& PENIWATI, K. 1998. Aggregating individual judgments and priorities with the analytic hierarchy process. European Journal of Operational Research, 108:165-169.

FRAME, W.S., PADHI, M. \& WOOSLEY, L. 2001. The effect of credit scoring on small business lending in low- and moderate-income areas, Federal Reserve Bank of Atlanta. Working Paper 2001-6.

GIRGINER, N. 2008. Ticari kredi taleplerinin değerlendirilmesine çok kriterli yaklaşım: Özel ve devlet bankası karşılaştırması", Muhasebe ve Finansman Dergisi, 37:132-141.

HSIA, K.H. \& WU, J.H. 1997. A study on the data preprocessing in Grey relational analysis. Journal of Chinese Grey System, 1:47-53.

HUANG, C.L., CHEN, M.C. \& WANG, C.J. 2007. Credit scoring with a data mining approach based on support vector machines. Expert Systems with Applications, 33:847-856.

İÇ, Y.T. \& YURDAKUL, M. 2000. Analitik hiyerarşi süreci (AHS) yöntemini kullanan bir kredi değerlendirme sistemi. Gazi Üniversitesi Mühendislik Mimarlık Fakültesi Dergesi, 15(1):1-14.

JAVALGİ, R.G, ARMACOST, R.L. \& HOSSEINİ, J.C. 1989. Using the analytical hierarchy process for bank management: Analysis of customer bank selection decisions. Journal of Business Research, 19(1): 33-49.

LEE, M., PHAM, H. \& ZHANG, X. 1999. A methodology for priority setting with application to software development process. European Journal of Operational Research, 118:375-89.

LIPOVETSKY, S. 1996. The synthetic hierarchy method: An optimizing approach to obtaining priorities in the AHP. European Journal of Operational Research, 93(3):550-564. 
MACHARIS C., SPRINGAEL J., DE BRUCKER K. \& VERBEKE A. 2004. PROMETHEE and AHP: The design of operational synergies in multicriteria analysis. Strengthening PROMETHEE with ideas of AHP. European Journal of Operational Research, 153:307-317.

SAATY, T.L. 1980. The analytic hierarchy process, New York: McGraw Hill.

SAATY, T.L. 1990. Eigenvector and logarithmic least squares. European Journal of Operational Research, 48:156-160.

SAATY, T.L. 1994. Fundamentals of decision making and priority theory with the AHP. Pittsburgh, PA: U.S.A: RWS Publications.

SAATY, T.L. 2000. Fundamentals of the analytic hierarchy process. Pittsburgh, PA: RWS Publications. SEKRETER, M.S., AKYÜZ, G. \& ÇETIN, E. 2004. Şirketlerin derecelendirilmesine ilişkin bir model önerisi: Gıda sektörüne yönelik bir Uygulama. Akdeniz İ.I.B.F. Dergisi, 8:139-155.

TUNG, S.L. \& TANG, S.L. 1998. A comparison of the Saaty's AHP and modified AHP for right and left Eigenvector inconsistency. European Journal of Operational Research, 106(1):123-128.

WU, W.Y., SHIH, H.A. \& CHAN, H.C. 2008. The analytic network process for partner selection criteria in strategic alliances. Expert Systems with Applications, 36(3):4646-4653.

WU, C.R., LIN, C.T. \& TSAI, P.H. 2010. Evaluating business performance of wealth management banks. European Journal of Operational Research, 207(2):971-979.

XU, Y. \& ZHANG, Y. 2009. An online credit evaluation method based on AHP and SPA. Commun Nonlinear Sci Numer Simulat, 14:3031-3036.

YURDAKUL, M. \& İÇ, Y.T. 2004. AHP approach in the credit evaluation of the manufacturing firms in Turkey. International Journal Of Production Economics, 88:269-289. 